\title{
Paleocene and Maastrichtian calcareous nannofossils from clasts in Pleistocene glaciomarine muds from the northern James Ross Basin, western Weddell Sea, Antarctica
}

\author{
D.K. Kulhanek \\ Department of Geological Sciences, Florida State University, 108 Carraway Building, Tallahassee, FL 32306-4100, USA (kulhanek@gly.fsu.edu)
}

Abstract Site NBP0602A-9, drilled during the SHALDRIL II cruise of the RV/IB Nathaniel B. Palmer, includes two holes located in the northern James Ross Basin in the western Weddell Sea, very close to the eastern margin of the Antarctic Peninsula. Sediment from both holes consists of very dark grey, pebbly, sandy mud, grading to very dark greenish grey, pebbly, silty mud in the lower $2.5 \mathrm{~m}$ of the second hole. In addition to abundant pebbles found throughout the cores, both holes contain numerous sedimentary clasts. Biostratigraphic analysis of diatom assemblages from the glaciomarine muds yields rare to few, poorly preserved diatoms. The mixed assemblage consists mostly of extant species, but also includes reworked taxa that range to the Miocene. The absence of Rouxia spp., however, suggests the sediment is late Pleistocene in age. The sedimentary clasts, on the other hand, are nearly barren of diatoms, but contain rare, moderately to well-preserved calcareous nannofossils. The clasts contain three distinct assemblages. Two clasts are assigned an early Maastrichtian age based on the presence of Biscutum magnum and Nephrolithus corystus, while one clast yields a late Maastrichtian age based on the presence of Nephrolithus frequens. These samples also contain other characteristic Late Cretaceous species, including Biscutum notaculum, Cribrosphaerella daniae, Eiffellithus gorkae, Kamptnerius magnificus, and Prediscosphaera bukryi. Two samples yield an early Paleocene assemblage dominated by Hornibrookina teuriensis. The Maastrichtian assemblages are similar to those found in the López de Bertodano Formation on Seymour and Snow Hill Islands, making it the likely source area for the Cretaceous clast material. Although no calcareous nannofossils have been reported from Paleocene formations on these islands, the occurrence of calcareous foraminifers suggests other calcareous plankton may be present; thus the Paleocene clasts likely also originated from the Seymour Island area.

Citation: Kulhanek, D.K. (2007), Paleocene and Maastrichtian calcareous nannofossils from clasts in Pleistocene glaciomarine muds from the Northern James Ross Basin, Western Weddell Sea, Antarctica, in Antarctica: A Keystone in a Changing World - Online Proceedings of the $10^{\text {th }}$ ISAES, edited by A.K. Cooper and C.R. Raymond et al., USGS Open-File Report 2007-1047, Short Research Paper 019, 5 p.; doi:10.3133/of2007-1047.srp019.

\section{Introduction}

The SHALDRIL II Cruise NBP0602A was the second cruise to the Antarctic margin on which a drilling rig was installed on the RV/IB Nathaniel B. Palmer to allow penetration of glacial overburden. This cruise drilled 12 sites in the James Ross Basin in the western Weddell Sea, very close to the Antarctic Peninsula (Fig. 1), with the objective of obtaining cores from key intervals during the evolution of the Antarctic cryosphere, including the upper Eocene/lower Oligocene, upper Oligocene, and Miocene. Although a particularly difficult ice year precluded drilling at any one site for extended periods of time, the cruise was a success, obtaining cores from each of the targeted intervals. With multiyear sea-ice coverage approaching $100 \%$ near the proposed sites, several attempts yielded core, but did not reach the targeted interval.

Site NBP0602A-9 targeted lower Oligocene sediments at a location just east of James Ross Island (Fig. 1). Two holes were attempted at Site 9, but both had to be abandoned due to approaching ice prior to reaching the target interval situated some 20 meters below the seafloor (mbsf). Hole 9A reached 4.23 mbsf, recovering approximately $2 \mathrm{~m}$ of core, whereas Hole 9B penetrated to $10 \mathrm{mbsf}$, recovering $5.6 \mathrm{~m}$ of core. Although neither hole reached the intended target, both yielded numerous sedimentary clasts that, upon shipboard examination, contain well-preserved calcareous nannofossils.

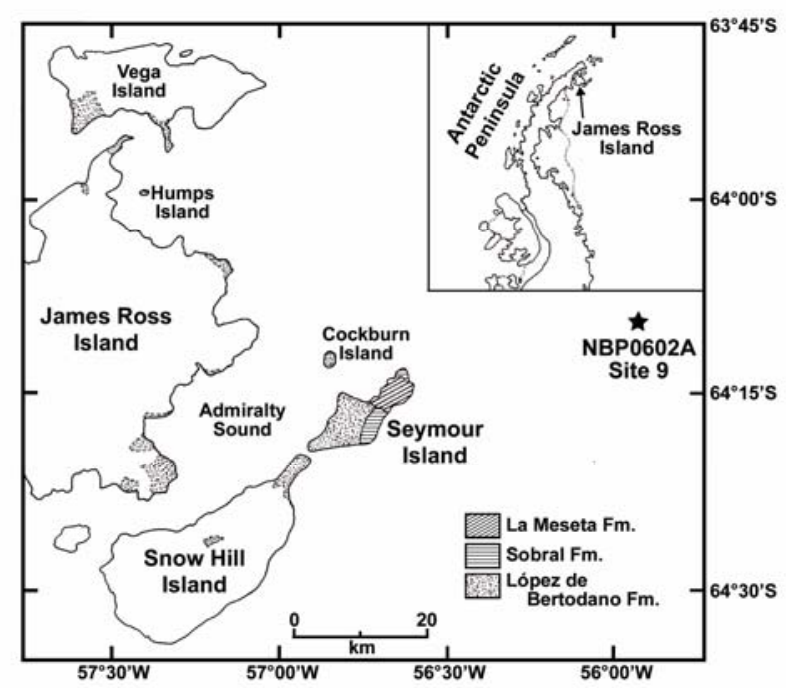

Figure 1. Locality map for the western Weddell Sea and James Ross Island region of the Antarctic Peninsula. Site NBP0602A-9 is indicated with a star. Outcrops of the Maastrichtian-Paleocene López de Bertodano Formation, Paleocene Sobral Formation, and Eocene La Meseta Formation in the James Ross Island region are shown. The inset figure shows the location of James Ross Island on the Antarctic Peninsula. (Modified from Pirrie et al., 1997.) 


\section{Site NBP0602A-9}

Sediment from both Holes NBP0602A-9A and -9B consists of very dark grey to very dark greenish grey pebbly sandy or silty mud. Pebble lithologies in both holes include volcanics, quartzites, and poorly indurated sedimentary clasts, although they are not present in Hole 9B below 8.7 mbsf (Anderson et al., 2006). The mud matrix contains a mixed assemblage of rare to few poorly preserved diatoms. The presence of extant taxa and the absence of Rouxia spp. suggest a late Pleistocene age for the drilled sections, whereas the occurrence of older taxa (including Actinocyclus ingens and Denticulopsis vulgaris) is attributed to reworking (Anderson et al., 2006). Sedimentary clasts range in size from a few millimeters to two centimeters in diameter, and consist of sandy mud with only trace numbers of broken diatoms that are probably contamination for the surrounding matrix. Shipboard examination of two clasts from Hole 9A found a rare, but diverse assemblage of moderately to well-preserved Maastrichtian calcareous nannofossils.

\section{Materials and Methods}

Eight clasts from Hole NBP0602A-9B were sampled and examined for calcareous nannofossils. Samples were prepared following standard smear slide procedures, and examined on a Zeiss Axioskop microscope at 1250x. At least 800 fields of view (FOVs) were examined for each sample. Calcareous nannofossils were very rare, and therefore reported as total number of specimens found during examination.

\section{Results}

Five of the clasts contain biostratigraphically useful assemblages, two are barren or nearly so, and one contains a mixed assemblage of Cretaceous and Paleogene calcareous nannofossils (Table 1). Calcareous nannofossils are quite rare, but moderately to well preserved within the clasts. The first sample, NBP0602A$9 B-2 R_{a}, 12 \mathrm{~cm}$, is barren of calcareous nannofossils. Sample NBP0602A-9B-2R, $21 \mathrm{~cm}$ contains a wellpreserved Paleocene assemblage. The most abundant species in this clast is Hornibrookina teuriensis, a species typical of Paleocene southern high latitudes (Wei and Pospichal, 1991). Biostratigraphically useful species include Cruciplacolithus intermedius, Cr. tenuis, and Chiasmolithus danicus. Several specimens assigned to Neocrepidolithus spp. occur in the sample, as does Braarudosphaera bigelowii and the holococcolith Lanternithus duocavus. Sample NBP0602A-9B-2R, 126 $\mathrm{cm}$ contains a very similar Paleocene assemblage, with $H$. teuriensis the most abundant species. In addition to $B$. bigelowii and a single Neocrepidolithus spp., this sample contains a very small placolith assigned to Neobiscutum spp.

Sample NBP0602A-9B-2R $\mathrm{R}_{\mathrm{a}}, 71 \mathrm{~cm}$ contains a mixed assemblage of Cretaceous and Paleogene species. Calcareous nannofossils are very rare throughout the sample; only seven specimens were observed in the 800 FOVs examined. Two fragments of Thoracosphaera spp. and a $B$. bigelowii fragment are not biostratigraphically useful. Biscutum notaculum and a fragment of Kamptnerius magnficus are indicative of a Cretaceous age. This sample also contains a well preserved specimen of Octolithus multiplus, which ranges from the Maastrichtian to the Paleogene.

Sample NBP0602A-9B-2R, $79 \mathrm{~cm}$ contains a late Maastrichtian assemblage. The most abundant species in this sample is represented by Prediscosphaera bukryi, which has a range restricted to the late CampanianMaastrichtian. Other biostratigraphically useful species present are Nephrolithus frequens and Cribrosphaerella daniae. This clast also contains Acuturris scotus, B.

Table 1. Distribution of Cretaceous and Paleogene calcareous nannofossil species in clasts from Site NBP0602A9. K/P survivors are species that survived the Cretaceous/Paleogene boundary extinction event.

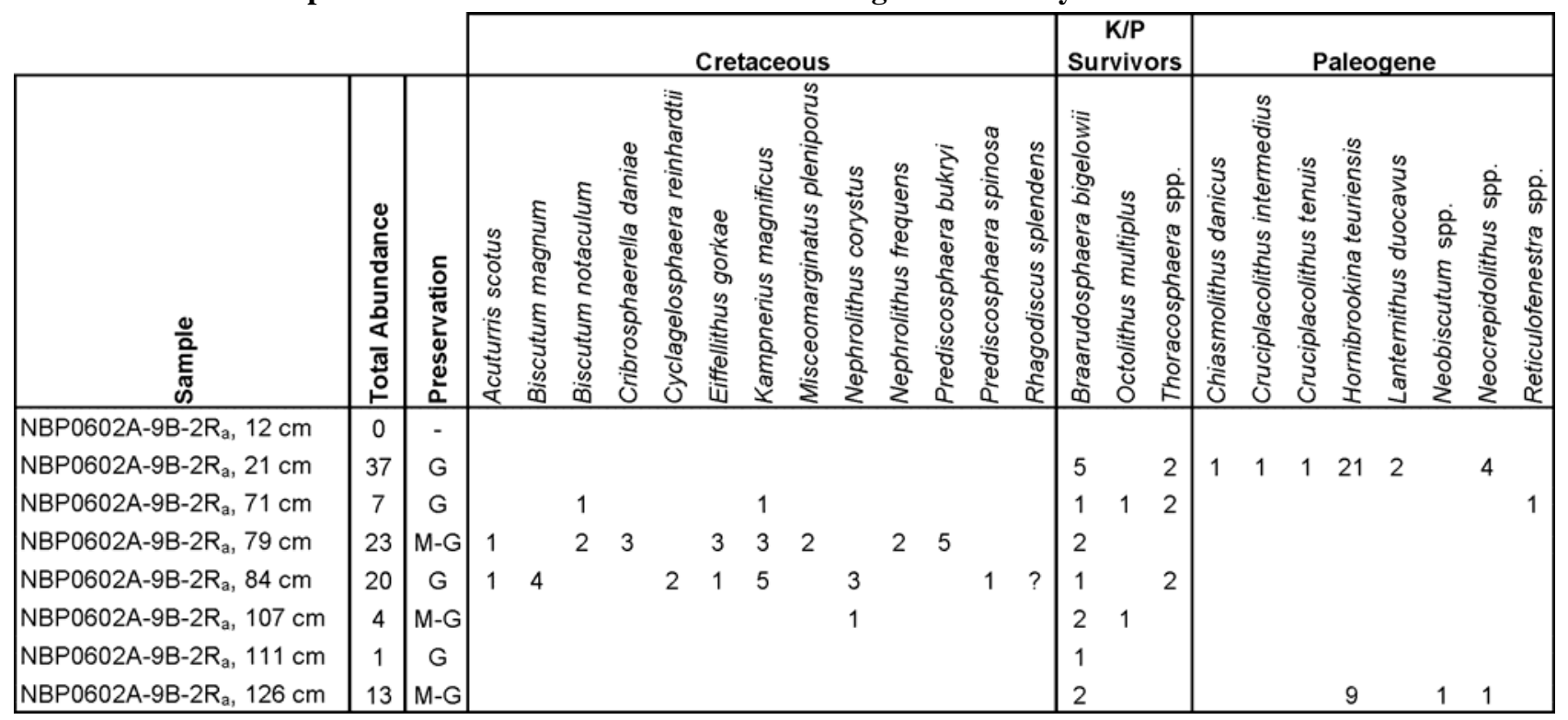


bigelowii, B. notaculum, Eiffellithus gorkae, Misceomarginatus pleniporus, and fragments of $K$. magnificus

Sample NBP0602A-9B-2R, $84 \mathrm{~cm}$ also contains rare Maastrichtian calcareous nannofossils. The presence of Biscutum magnum and Nephrolithus corystus indicate a somewhat older age than the previous sample. The most abundant species is $K$. magnificus, several specimens of which are whole and well preserved. The overall assemblage is generally similar to that of the previous sample, and includes A. scotus, E. gorkae, and Prediscosphaera spinosa. Other species present include Thoracosphaera spp., small Cyclagelosphaera reinhardtii, and a single broken specimen of what appears to be Rhagodiscus splendens. Sample NBP0602A-9B-2 $\mathrm{R}_{\mathrm{a}}$, $107 \mathrm{~cm}$ contains a sparse assemblage that includes $N$. corystus, B. bigelowii, and O. multiplus. The presence of $N$. corystus suggests this clast is the same age as the clast from $84 \mathrm{~cm}$. Only a single specimen of $B$. bigelowii was found in the final clast (Sample NBP0602A-9B-2R, 111 $\mathrm{cm})$.

\section{Discussion \\ Clast Ages}

Five of the seven clasts that contain calcareous nannofossils can be assigned to a biostratigraphic zone based on the assemblages present. The Paleocene samples (NBP0602A-9B-2R, $21 \mathrm{~cm}$ and $126 \mathrm{~cm}$ ) are assigned to early Paleocene Antarctic Zone NA4 (Wei and Pospichal, 1991) based on the presence of Ch. danicus and absence of Prinsius martinii in the former clast. Although the latter clast did not yield any biostratigraphic markers, the assemblage is very similar to that in the former, and thus is presumed to come from the same horizon.

Sample NBP0602A-9B-2Ra, $79 \mathrm{~cm}$ contains a late Maastrichtian assemblage assigned to the $C$. daniae Subzone of the $N$. frequens Zone of Pospichal and Wise (1990) based on the presence of these species, and the absence of $N$. corystus. Sample NBP0602A-9B-2R $a$ $\mathrm{cm}$ contains an early Maastrichtian assemblage assigned to the B. magnum Zone of Pospichal and Wise (1990) based on the presence of this species. Although Sample NBP0602A-9B-2R $\mathrm{R}_{\mathrm{a}}, 107 \mathrm{~cm}$ did not contain B. magnum, it does contain an older assemblage compared to the clast at $79 \mathrm{~cm}$ based on the presence of $N$. corystus, which has a last occurrence shortly after the first occurrence of $N$. frequens. The presence of $N$. corystus therefore supports an early to earliest late Maastrichtian age for this clast, potentially from the same horizon as the clast from $84 \mathrm{~cm}$.

\section{Clast Provenance}

Cretaceous and Paleocene sediments occur in outcrops on Antarctic Peninsular islands along the western margin of the James Ross Basin (e.g., Rinaldi, 1982; Macellari and Huber, 1982; Macellari, 1988; Pirrie et al., 1997; Crame et al., 2004). The fossiliferous López de Bertodano Formation, which crops out on Seymour, Snow Hill, and James Ross Islands (Fig. 1) spans the upper lower Maastrichtian to the Danian based on diatom, foraminifer, and calcareous nannofossil assemblages (e.g., Huber et al., 1983; Harwood, 1988; Huber, 1988; Crame et al., 2004). The overlying Sobral Formation is also Paleocene in age based on diatoms (Harwood, 1988) and foraminifers (Huber, 1988).

There have been very few studies that report Cretaceous calcareous nannofossils from outcrops on Seymour Island (Huber et al., 1983; Concheyro et al., 1991; and Concheyro et al., 1995) and Snow Hill Island (Concheyro et al., 1995 and Robles Hurtado and Concheyro, 1995). Huber et al. (1983) reported wellpreserved calcareous nannofossils from the López de Bertodano Formation on Seymour Island. The assemblage consists of Maastrichtian taxa, with the exception of $N$. corystus (latest Campanian to middle Maastrichtian), and is dominated by B. bigelowii. Concheyro et al. (1991) also report a well-preserved Maastrichtian flora from this formation on Seymour Island. Robles Hurtado and Concheyro (1995) find a similar, but poorly preserved Maastrichtian assemblage from the López de Bertodano Formation of Snow Hill Island. Species composition is similar to those reported from the Cretaceous clasts in this study. This, coupled with the proximity of Seymour and Snow Hill Islands, suggests the López de Bertodano Formation in those locations is the likely source for the Maastrichtian clasts.

No calcareous nannofossils have been reported from Paleocene sequences in this area, although calcareous foraminifers do occur above a dissolution facies in the lowermost Paleocene López de Bertodano Formation and in the lowermost unit of the overlying Sobral Formation on Seymour Island (Huber, 1988). Despite a dearth of reported nannofossils from the area, the Paleocene rocks of Seymour Island are the most likely provenance for the two Paleocene clasts found in this study.

\section{Summary}

Clasts found in Pleistocene glaciomarine muds of Site NBP0602A-9 contain diverse Maastrichtian and Paleocene calcareous nannofossil assemblages. These assemblages represent three distinct ages: early Maastrichtian, late Maastrichtian, and early Paleocene. The Maastrichtian assemblages are similar to those found in the López de Bertodano Formation on neighboring Seymour and Snow Hill Islands, making it the likely source area for the clast material. Although no calcareous nannofossils have been reported from Paleocene formations in the area, the occurrence of calcareous foraminifers suggests other calcareous plankton may be present; thus the Paleocene clasts likely also originated from the Seymour Island area.

Acknowledgements I would like to thank Steve Bohaty for providing the sampled clast material, as well as Sherwood "Woody" Wise and Simon Nielsen, who provided helpful suggestions for the initial manuscript. This manuscript was significantly improved by the comments of co-editor John Barron and reviewers David Watkins and Brian Huber. This study was supported by NSF grant 0125526 to S.W. Wise. 

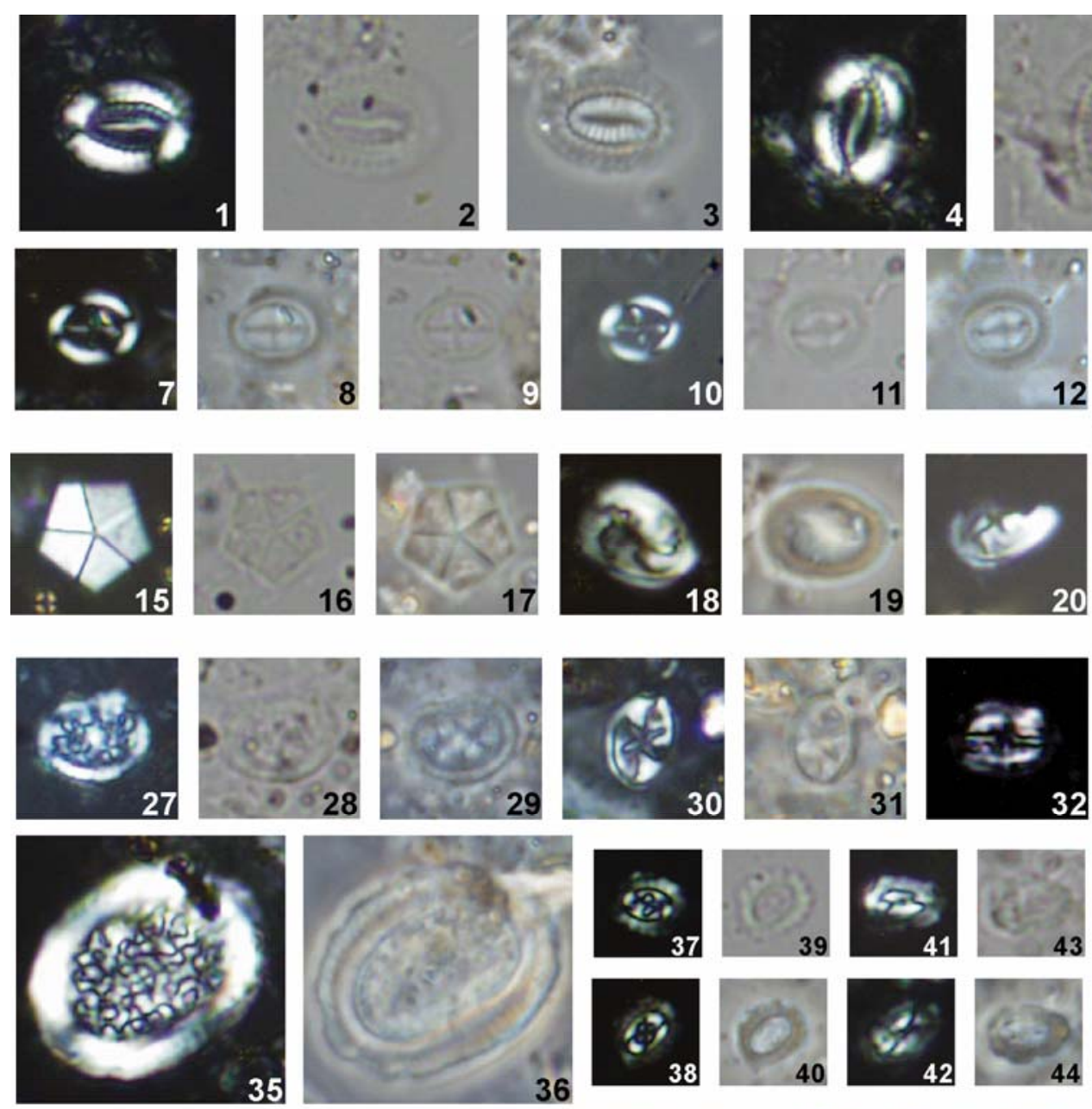

36
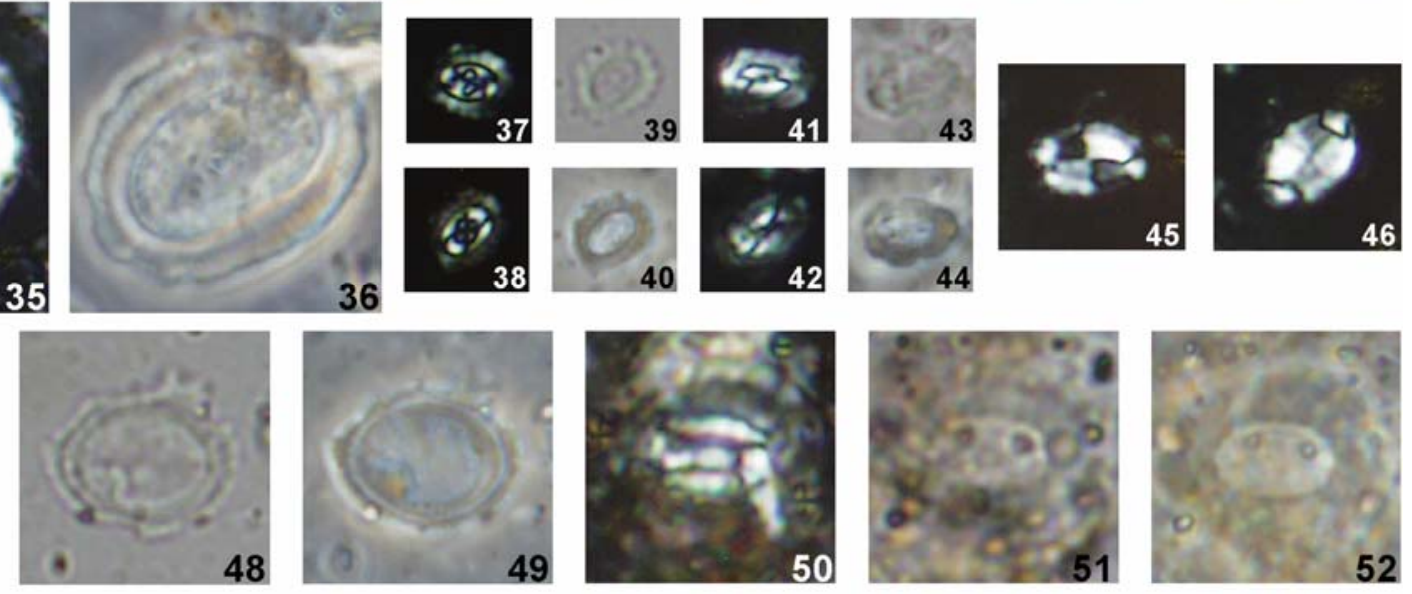

Plate 1. Micrographs taken with an Olympus DP11 digital camera on a Zeiss Axioskop 2, using a 100x objective and 1.25 optivar. All figures from Core NBP0602A-9B-2R ; clast depth listed after each species. Light micrography; XP = cross-polarized light, $\mathrm{PL}=$ plain-transmitted light, $\mathrm{PH}=$ phase-contrast light. Fig. 1-6. Hornibrookina teuriensis Edwards, 1973, 21 cm, 1 (XP), 2 (PL), 3 (PH), 4 (different specimen, XP), 5 (PL), 6 (PH). Figs. 7-9. Cruicplacolithus intermedius van Heck and Prins, 1987, 21 cm, 7 (XP), 8 (PH), 9 (PL). Figs. 10-12. Cruciplacolithus tenuis (Stradner, 1961) Hay and Mohler in Hay et al., 1967, 21 cm, 10 (XP), 11 (PL), 12 (PH). Figs. 13 and 14. Chiasmolithus danicus (Brotzen, 1959) van Heck and Perch-Nielsen, 1987, 21 cm, 13 (XP), 14 (PH). Figs. 15-17. Braarudosphaera bigelowii (Gran and Braarud, 1935) Deflandre, 1947, 21 cm, 15 (XP), 16 (PL), 17 (PH). Figs. 18-24. Neocrepidolithus spp., 21 cm, 18 (XP), 19 (PH), 20 (different specimen, XP), 21, 22 (different specimen, XP), 23 (PL), 24 (PH). Figs. 25 and 26. Lanternithus duocavus Locker, 1967, 21 cm, 25, 26 (XP). Figs. 27-29. Nephrolithus frequens Górka, 1957, 79 cm, 27 (XP), 28 (PL), 29 (PH). Figs. 30 and 31. Eiffellithus gorkae Reinhardt, 1965, 79 cm, 30 (XP), 31 (PH). Figs. 32-34. Misceomarginatus pleniporus Wind and Wise in Wise and Wind, 1977, 79 cm, 32, 33 (XP), 34 (PH). Figs. 35 and 36. Cribrosphaerella daniae Perch-Nielsen, 1973, 79 cm, 35 (XP), 36 (PH). Figs. 37-40. Prediscosphaera bukryi PerchNielsen, 1973, 79 cm, 37, 38 (XP), 39 (PH), 40 (PH). Figs. 41-44. Biscutum notaculum Wind and Wise in Wise and Wind, 1977, 79 cm, 41, 42 (XP), 43 (PL), 44 (PH). Figs. 45 and 46. Octolithus multiplus (Perch-Nielsen, 1973) Romein, 1979, 71 cm, 45, 46 (XP). Figs. 47-49. Kamptnerius magnificus Deflandre, 1959, 79 cm, 47 (XP), 48 (PL), 49 (PH). Figs. 50-52. Biscutum magnum Wind and Wise in Wise and Wind, 1977, 84 cm, 50 (XP), 51, 52 (PH). 


\section{References}

Anderson, J. B., Manley, P. L., Wise, S. W., Smith Wellner, J., Kulhanek, D. K., and the SHALDRIL II Scientific Party (2006), SHALDRIL II 2006 NBP0602A Cruise Report, available online at: http://shaldril.rice.edu/PDFs/NBP0602A.pdf.

Concheyro, A., Olivera, A., Santillana, S., Marenssi, S., and Rinaldi, C. (1991), Nanofosiles calcareos del cretacico superior de isla marambia, Antartica, Congreso Geologico Chileno, Resumenes Presentados 6, 825-828.

Concheyro, A., Robles Hurtado, G. M., and Olivero, E. B. (1995), Sedimentology and calcareous nannofossils from the Upper Cretaceous-Paleocene of James Ross Island area, Antarctica, VII International Symposium on Antarctic Earth Sciences, p. 88 (abstract).

Crame, J. A., Francis, J. E., Cantrill, D. J., and Pirrie, D. (2004), Maastrichtian stratigraphy of Antarctica, Cretaceous Research, 25, 411-423.

Harwood, D. M. (1988), Upper Cretaceous and lower Paleocene diatom and silicoflagellate biostratigraphy of Seymour Island, eastern Antarctic Peninsula, in Geology and Paleontology of Seymour Island, Antarctica Peninsula, edited by R. M. Feldmann, and M. O. Woodburne, GSA Memoir 169, pp. 55-129.

Huber, B. T. (1988), Upper Campanian-Paleocene foraminifera from the James Ross Island region, Antarctic Peninsula in Geology and Paleontology of Seymour Island, Antarctica Peninsula, edited by R. M. Feldmann, and M. O. Woodburne, GSA Memoir 169, pp. 163-252.

Huber, B. T., Harwood, D. M., and Webb, P. N. (1983), Upper Cretaceous microfossil biostratigraphy of Seymour Island, Antarctic
Peninsula, Antarctic Journal of the United States (1983 annual edition), 17(5), 72-74.

Macellari, C. E. (1988), Stratigraphy, sedimentology, and paleoecology of Upper Cretaceous/Paleocene shelf-deltaic sediments of Seymour Island, in Geology and Paleontology of Seymour Island, Antarctica Peninsula, edited by R. M. Feldmann, and M. O. Woodburne, GSA Memoir 169, pp. 25-53.

Macellari, C., and Huber, B. T., (1982), Cretaceous stratigraphy of Seymour Island, East Antarctic Peninsula, Antarctic Journal of the United States (1982 annual edition), 17(5), 68-70.

Pirrie, D., Crame, J. A., Lomas, S. A., and Riding, J. B. (1997), Late Cretaceous stratigraphy of the Admiralty Sound region, James Ross Basin, Antarctica, Cretaceous Research, 18, 109-137.

Pospichal, J. J., and Wise, S. W. (1990), Maestrichtian calcareous nannofossil biostratigraphy of Maud Rise ODP Leg 113 Sites 689 and 690, Weddell Sea, in Proc. ODP, Sci. Results, 113, edited by P. F. Barker, J. P. Kennett, et al., pp. 465-487, College Station, TX.

Rinaldi, C. A. (1982), The Upper Cretaceous in the James Ross Island Group, in Antarctic Geoscience, edited by C. Craddock, pp. 281-286, The University of Wisconsin Press, Madison, Wisconsin.

Robles Hurtado, G. M., and Concheyro, A. (1995), Sedimentologia y bio-cronoestratigrafia (nanofosiles calcareos) del Nunatak Sanctuary Cliffs (cretacico superior), Isla Cerro Nevado, Antartica, VI Congreso Argentino de Paleontologia y Bioestragrafia, Actas, 231-237.

Wei, W., and Pospichal, J. J. (1991), Danian calcareous nannofossil succession at Site 738 in the Southern Indian Ocean, in Proc. ODP, Sci. Results, 119, edited by J. Barron, B. Larsen, et al., pp. 495-512, College Station, TX. 